ISSN: $1410-8917$

Jurnal Kimia

Sains \&

Aplikasi
Jurnal Kimia Sains dan Aplikasi Journal of Scientific and Applied Chemistry

Journal homepage: http://ejournal.undip.ac.id/index.php/ksa

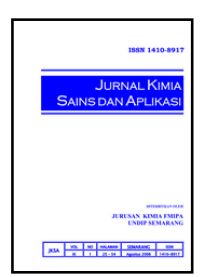

\title{
Isolasi Senyawa Triterpenoid dari Daun Ketapang Kencana (Terminalia Muelleri Benth) dan Uji Aktivitas Sitotoksik dengan Metode Brine Shrimp Lethality Test (BSLT)
}

\author{
Veronika Adelina Hartini ${ }^{a}$, Khairul Anam ${ }^{a^{*}}$, Bambang Cahyono ${ }^{\mathrm{a}}$ \\ a Organic Chemistry Laboratory, Chemistry Department, Faculty of Sciences and Mathematics, Diponegoro University, Jalan Prof. \\ Soedarto, Tembalang, Semarang \\ * Corresponding author: k.anam@live.undip.ac.id
}

\section{Article Info}

Keywords:

Terminalia muelleri Benth.,

Triterpenoid, cytotoxic
Kata kunci:

Terminalia muelleri Benth., triterpenoid, sitotoksik

\section{Abstract}

Ketapang kencana (Terminalia muelleri Benth.) is one of the flowering plants of the Combretaceae family. This family has been widely used as a traditional medicine for antibacterial, antifungal, and antiviral. However, the use of T. muelleri as a traditional medicine has not been widely known. This study aim was to determine the content of triterpenoid compounds and cytotoxic activity in T. muelleri. The study consisted of three stages which were isolation of triterpenoid compounds by extraction, followed by liquid-liquid extraction fractionation, separation of compound components by vacuum liquid chromatography (KCV) and purification using TLC. Characterization of pure isolated compounds with FTIR, UV-Vis, and GC-MS spectrometers. The cytotoxic activity test was performed on ethanol extract, $n$-hexane fraction, ethyl acetate fraction, and methanol-water fraction by BSLT method. The isolates obtained were white solids with a yield of $0.28 \%(\mathrm{w} / \mathrm{w})$. Characterization of isolates with $\mathrm{UV}-\mathrm{Vis}$ spectrophotometer showed an absorption at $204 \mathrm{~nm}$ which was a cut off solvent. Based on the FTIR spectrogram showing the presence of $-\mathrm{OH}, \mathrm{C}=\mathrm{C}, \mathrm{C}=\mathrm{O},-\mathrm{CH}_{3}$ and $-\mathrm{CH}_{2}$. While the $\mathrm{MS}$ spectroscopy showed that the isolates had molecular weights of $577 \mathrm{~g} / \mathrm{mol}$ and had similar fragmentation patterns of lupeol compounds $(\mathrm{SI}=88 \%)$. The results of cytotoxic activity test showed ethanol extract and $n$-hexane fraction were not toxic while ethyl acetate fraction and methanol-water fraction had slightly toxic properties with $\mathrm{LC}_{50}$ price of $100 \mathrm{ppm}$ and 78,735 ppm respectively.

\section{Abstrak}

Ketapang kencana (Terminalia muelleri Benth.) merupakan salah satu tumbuhan berbunga dari suku Combretaceae. Suku ini telah banyak dimanfaatkan sebagai obat tradisional untuk antibakteri, antifungi, dan antivirus. Akan tetapi, penggunaan $T$. muelleri sebagai obat tradisional belum banyak diketahui. Penelitian ini bertujuan untuk mengetahui kandungan senyawa triterpenoid dan aktivitas sitotoksik pada T. muelleri. Penelitian dibagi menjadi tiga tahap yaitu isolasi senyawa triterpenoid dengan cara ekstraksi, diikuti fraksinasi secara ekstraksi cair-cair, pemisahan komponen senyawa dengan kromatografi cair vakum (KCV) dan pemurnian menggunakan KLT. Karakterisasi senyawa murni hasil isolasi dengan spektrometer FTIR, UV-Vis, dan GCMS. Uji aktivitas sitotoksik dilakukan terhadap ekstrak etanol, fraksi $n$-heksana, fraksi etil asetat, dan fraksi metanol-air dengan metode BSLT. Isolat yang diperoleh berupa padatan berwarna putih dengan rendemen $0,28 \%(b / b)$. Karakterisasi isolat dengan spektrofotometer UV-Vis menunjukkan adanya serapan pada $204 \mathrm{~nm}$ yang merupakan cut off pelarut. Berdasarkan spektrogram FTIR menunjukkan adanya gugus $-\mathrm{OH}, \mathrm{C}=\mathrm{C}, \mathrm{C}=\mathrm{O},-\mathrm{CH} 3$ dan $-\mathrm{CH}$. Sedangkan spektrogram MS menunjukkan bahwa 
isolat memiliki bobot molekul $577 \mathrm{~g} / \mathrm{mol}$ dan memiliki pola fragmentasi mirip senyawa lupeol ( $\mathrm{SI}=88 \%$ ). Hasil uji aktivitas sitotoksik menunjukkan ekstrak etanol dan fraksi nheksana bersifat tidak toksik sedangkan fraksi etil asetat dan fraksi metanol-air memiliki sifat sedikit toksik dengan harga $\mathrm{LC}_{50}$ berturut-turut $100 \mathrm{ppm}$ dan 78,735 ppm.

\section{Pendahuluan}

Masyarakat Indonesia telah lama memanfaatkan tumbuhan obat sebagai obat tradisional. Obat tradisional adalah bahan atau ramuan bahan yang berasal dari tumbuh-tumbuhan, hewan, dan mineral, sediaan sarian (galenik) atau campuran dari bahan tersebut yang secara turun-temurun telah digunakan untuk pengobatan. Wilayah nusantara Indonesia memiliki 40.000 spesies tanaman dan 940 diantaranya berkhasiat obat. Indonesia merupakan salah satu penghasil tanaman obat terbesar di dunia. Mengingat semakin meningkatnya kebutuhan akan obat-obatan maka perlu dilakukan penelitian mengenai komponen aktif yang ada pada tumbuhan obat tersebut serta toksisitasnya sebagai obat.

Salah satu tumbuhan yang dapat dimanfaatkan sebagai obat adalah ketapang kencana (Terminalia muelleri Benth.). T. mulleri merupakan salah satu tumbuhan berbunga dari genus Terminalia dan keluarga Combretaceae. Tumbuhan ini dikenal di Indonesia sebagai ketapang kencana. T. mulleri tersebar secara luas di negara tropis seperti India, Indonesia dan Amerika Utara [1]. Tumbuhan ini belum banyak dikembangkan di Indonesia. Namun, ekstrak Genus Terminalia telah diketahui aktivitasnya sebagai antikanker, antioksidan, antifungi, dan sebagai inhibitor enzim $\alpha$-glukosidase $[2,3]$. Genus Terminalia mengandung metabolit sekunder triterpenoid siklik dan turunannya, flavonoid, tanin dan senyawa aromatik lainnya [4].

Triterpenoid yang merupakan salah satu golongan senyawa metabolit sekunder, telah banyak dipergunakan dalam kehidupan sehari-hari sebagai obat seperti diabetes, gangguan menstruasi, patukan ular, gangguan kulit, kerusakan hati dan malaria. Senyawa triterpenoid mempunyai nilai ekologi bagi tumbuhan karena senyawa ini bekerja sebagai antifungi, insektisida, antipemangsa, antibakteri dan antivirus. Bigham dkk. [5] menyatakan bahwa triterpenoid yang mempunyai aktifitas sebagai antibakteri adalah triterpenoid saponin dan triterpenoid glikosida.

Jenis terpenoid yang berhasil diisolasi dari Genus Terminalia antara lain asam 3-asetilmaslinat dari Terminalia alata dan terminalin A dari Terminalia glaucescens [6]. Mengingat jenis senyawa triterpenoid yang terkandung di dalam T. mulleri belum pernah dilaporkan maka perlu dilakukan isolasi dan identifikasi senyawa triterpenoid dari T. mulleri.

Penelitian ini bertujuan untuk mengisolasi dan mengidentifikasi senyawa triterpenoid dari daun $T$. mulleri Benth. serta menguji aktivitas sitotoksiknya dengan metode Brine Shrimp Lethality Test (BSLT).

\section{Metode Penelitian}

Bahan

Daun T. muelleri Benth., aquades, asam asetat anhidrid, asam sulfat pekat, metanol, etanol, nheksana, etil asetat, diklorometan, silika gel 60H (Merck EM 7734), plat KLT, KLT preparatif, kertas saring, Tween ${ }^{\circledR} 20$, telur Artemia salina Leach. dan garam dapur.

\section{Alat}

Gelas beaker $1 \mathrm{~L}$, erlenmeyer $2 \mathrm{~L}$, labu takar $50 \mathrm{~mL}$, gelas ukur $250 \mathrm{~mL}$, termometer, pipet tetes, cawan penguapan, chamber KLT, botol vial $10 \mathrm{~mL}$, kolom kromatografi, pompa vakum, rotaryvaporator, bejana penetesan telur Artemia salina, neraca analitis, lampu UV, spektrometer FTIR, UV-Vis, dan GCMS.

\section{Preparasi Sampel}

Daun T. muelleri diperoleh dan dideterminasi di Pusat Konservasi Tumbuhan Kebun Raya Bogor. Daun dibersihkan dari debu, pasir dan pengotor lainnya, kemudian diangin-anginkan hingga kering dan dijadikan serbuk menggunakan blender.

\section{Ekstraksi Triterpenoid}

Sebanyak $1 \mathrm{~kg}$ serbuk kering T. muelleri diekstraksi dengan cara maserasi menggunakan $3 \mathrm{~L}$ pelarut etanol. Filtrat yang didapat dipekatkan dengan rotary vacuum evaporator sehingga diperoleh ekstrak etanol dengan berat 42 gram.

\section{Fraksinasi Ekstrak Etanol}

Sebanyak 24 gram ekstrak etanol difraksinasi dengan metode ekstraksi cair-cair menggunakan pelarut berturut-turut $n$-heksana, etil asetat, dan metanol. Tiga fraksi yang diperoleh yaitu fraksi $n-$ heksana, fraksi etil asetat, dan fraksi metanol ditentukan fraksi yang kaya triterpenoid menggunakan pereaksi Liebermann-Burchard (LB). Uji positif keberadaan triterpenoid ditunjukkan dengan timbulnya warna merah.

\section{Pemisahan Triterpenoid}

Fraksi yang positif terhadap pereaksi LB diisolasi kandungan triterpenoidnya. Pemisahan dilakukan dengan metode kromatografi cair vakum. Silica gel $60 \mathrm{H}$ digunakan sebagai fase diam dan n-heksana, diklorometana, etil asetat, dan metanol sebagai fase gerak yang dialirkan secara gradient berdasarkan peningkatan kepolaran.

\section{Uji Kemurnian Triterpenoid}

Isolat diuji kemurniannya menggunakan KLT dengan pelarut $n$-heksana, kloroform, diklorometana, etil asetat, metanol, dan campuran pelarut dengan 
perbandingan tertentu. Uji kemurnian juga dilakukan dengan KLT dua dimensi. Kemurnian ditunjukkan dengan terbentuknya noda tunggal.

\section{Karakterisasi Triterpenoid}

Karakterisasi senyawa triterpenoid dilakukan terhadap kristal hasil pemurnian menggunakan spektrometer FTIR, UV-Vis, dan GCMS.

\section{Uji Sitotoksik dengan Metode BSLT}

Uji sitotoksik dilakukan dengan membuat larutan sampel dalam air laut buatan dengan konsentrasi 25 ppm; 250 ppm; 2500 ppm. Sebanyak 0,125 gram ekstrak ditambah dengan $50 \mu \mathrm{L}$ Tween ${ }^{\circledR} 20$, dilarutkan pada media dalam labu takar hingga mencapai $50 \mathrm{~mL}$ sehingga diperoleh larutan induk dengan konsentrasi $2500 \mathrm{ppm}$. Kemudian dibuat larutan dengan konsentrasi $250 \mathrm{ppm}$ dan $25 \mathrm{ppm}$ dari pengenceran larutan induk. Sebanyak \pm 10 ekor larva Artemia salina Leach. dimasukkan ke dalam vial yang telah berisi $2 \mathrm{~mL}$ pada masing-masing larutan sampel konsentrasi 2500 ppm; 250 ppm; 25 ppm dan ditambahkan air laut buatan sampai $5 \mathrm{~mL}$. Hal tersebut dilakukan dengan tujuan untuk membuat larutan dengan konsentrasi tepat 1000 ppm; 100 ppm; 10 ppm.

Vial dijaga agar tetap mendapat penerangan. Jumlah Artemia salina Leach. yang mati dalam tiap botol gelas dihitung setelah 24 jam perlakuan. Dihitung dan ditentukan prosentase kematian [7]. Uji toksisitas dilakukan 3 kali replikasi untuk setiap ekstrak dan fraksi.

Untuk menentukan nilai $\mathrm{LC}_{50}$ digunakan Analisis Probit melalui hubungan konsentrasi dengan persen kematian.

\section{Hasil Dan Pembahasan}

Hasil uji fitokimia terhadap serbuk daun dan ekstrak etanol daun T. muelleri sesuai dengan metode yang dilakukan oleh Farnsworth [8] menunjukkan bahwa serbuk daun dan ekstrak etanol positif terhadap alkaloid, flavonoid, saponin, tanin galat, kuinon, dan triterpenoid.

Hasil uji fitokimia terhadap fraksi etil asetat menunjukkan bahwa fraksi tersebut memiliki kandungan triterpenoid. Pemisahan fraksi etil asetat dilakukan dengan kromatografi cair vakum (KCV) menggunakan silika gel $60 \mathrm{H}$ sebagai fasa diam dan $n-$ heksana, diklorometana, etil asetat, metanol sebagai fasa gerak yang diberikan secara gradien berdasarkan peningkatan kepolaran. Eluat dengan pola noda yang sama digabung menjadi kelompok fraksi besar, diuapkan pelarutnya dan diuji kualitatif terhadap triterpenoid menggunakan KLT dengan reagen semprot spesifik untuk triterpenoid yaitu Lieberman-Burchard (LB). Berdasarkan uji KLT terdapat satu kelompok fraksi yang memberikan respon positif terhadap reagen semprot LB yaitu fraksi A1-A11b dengan yang selanjutnya diberi nama EA. Kelompok fraksi EA ini kemudian diuji kualitatif dengan KLT menggunakan reagen semprot LB untuk mengetahui keberadaan triterpenoid. Pada $\mathrm{Rf} 0,45$ dan 0,68 secara visible terdapat noda yang berwarna merah keunguan dan di bawah lampu UV $365 \mathrm{~nm}$ befluoresensi biru kehijauan yang merupakan warna dari triterpenoid [9] ditunjukkan pada Gambar 1.

Berdasarkan hasil analisis KLT tersebut, selanjutnya dilakukan pemisahan dengan KLT preparatif menggunakan eluen campuran 2 pelarut $n$ heksana-diklorometana $(0,5: 9,5)$ dan menghasilkan 8 noda seperti ditunjukkan pada Gambar 2. Sebagian kecil dari plat KLT tersebut dipotong dan disemprot LB untuk mengetahui keberadaan triterpenoid. Hasil uji kualitatif menunjukkan bahwa noda dengan nomor urut 3 dan 4 positif triterpenoid. Untuk lebih memastikan keberadaan triterpenoid maka noda nomor 3 dan 4 dikerok dan diuji kualitatif dengan KLT menggunakan reagen semprot LB.

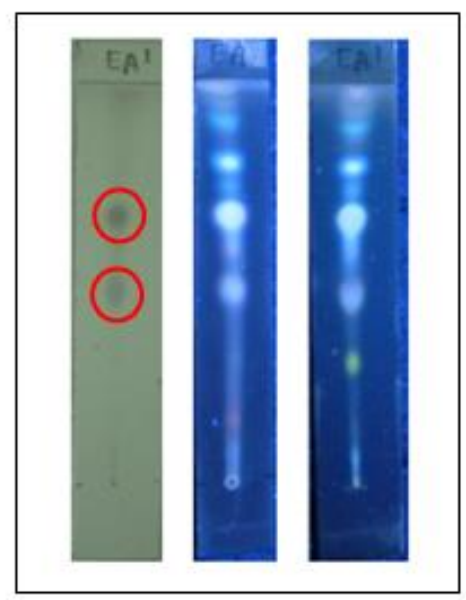

(A) (B) (C)

Gambar 1. KLT kelompok fraksi EA hasil KCV; (A) secara visible setelah disemprot Lieberman-Burchard,

(B) di bawah lampu UV $365 \mathrm{~nm}$ dengan asam sulfat $10 \%$ dan (C) di bawah lampu UV $365 \mathrm{~nm} \mathrm{LB}$

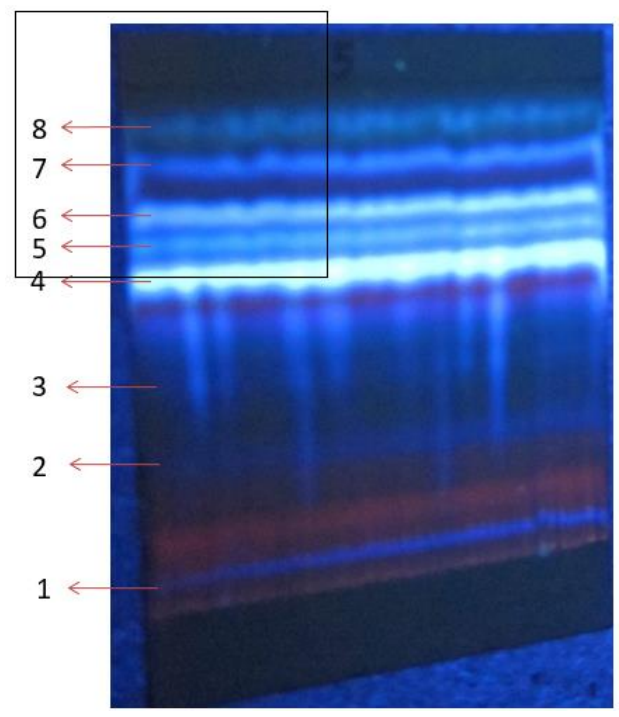

Gambar 2. Hasil KLT preparatif kelompok fraksi EA di bawah lampu UV $365 \mathrm{~nm}$ 
Uji kemurnian dilakukan dengan KLT dua dimensi menggunakan pelarut $n$-heksana-diklorometana $(0,5$ : 9,5) dan $n$-heksana-kloroform (3:7). Hasil KLT preparatif noda nomor 3 menunjukkan noda tunggal dengan fluoresensi berwarna merah muda di bawah lampu UV $365 \mathrm{~nm}$ dengan intensitas warna yang lemah. Hasil KLT preparatif noda nomor 4 menunjukkan noda tunggal dengan fluoresensi berwarna merah muda dengan intensitas warna kuat.

Isolat nomor 3 dan 4 yang telah relatif murni selanjutnya dikarakterisasi dengan spektroskopi UVVis, FTIR, dan GCMS. Namun, isolat nomor 3 tidak dapat dikarakterisasi karena jumlahnya yang sangat sedikit dan semakin berkurang selama proses penyimpanan.

Hasil serapan UV-Vis dalam pelarut metanol menunjukkan adanya serapan panjang gelombang 204 nm, ditunjukkan pada Gambar 3. Munculnya serapan pada panjang gelombang $204 \mathrm{~nm}$ merupakan salah satu ciri khas dari senyawa triterpenoid di mana serapan yang muncul merupakan serapan cut off pelarut yang digunakan. Metanol menyerap pada panjang gelombang lebih pendek dari $185 \mathrm{~nm}$ dan karenanya biasa digunakan untuk pelarut di dalam daerah UV. Bila metanol digunakan sebagai pelarut, serapan yang kuat terentang ke dalam daerah dekat UV, menghasilkan cut off di dalam daerah 200-220 nm [10].

Hasil analisis dengan spektrofotometer FTIR pada Gambar 4 menunjukkan gugus fungsi yang terdapat pada isolat.

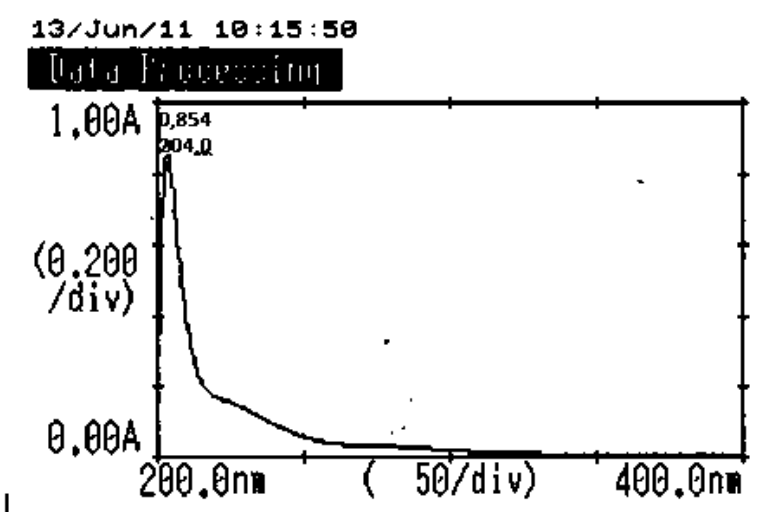

Gambar 3. Spektrogram UV-Vis isolat triterpenoid

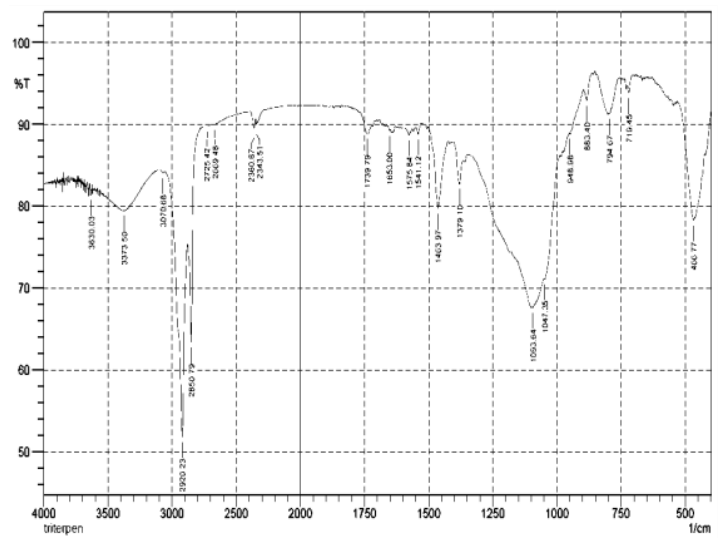

Gambar 4. Spektrogram FTIR isolat
Hasil analisis pola serapan FTIR terhadap isolat menunjukkan adanya serapan pada bilangan gelombang $3317,56 \mathrm{~cm}^{-1}$ yang merupakan serapan vibrasi ikatan OH. Vibrasi ikatan ini diduga merupakan vibrasi dari gugus alkohol yang didukung dengan munculnya serapan pada kuat pada bilangan gelombang 1093,64 $\mathrm{cm}^{-1}$ dan serapan lemah pada 1047,35 $\mathrm{cm}^{-1}$ dari vibrasi ulur C-O alkohol. Adanya serapan pada bilangan gelombang $3070,68 \mathrm{~cm}^{-1}$ merupakan serapan vibrasi ulur ikatan $=\mathrm{C}-\mathrm{H}$. Vibrasi ini diduga merupakan vibrasi dari $=\mathrm{C}-\mathrm{H}$ alifatik yang diperkuat dengan adanya bilangan gelombang $1575,84 \mathrm{~cm}-1$ dan $1541,12 \mathrm{~cm}^{-1}$ yang merupakan vibrasi ulur $\mathrm{C}=\mathrm{C}$ alifatik. Selain itu juga pita serapan pada daerah panjang gelombang $883,40 \mathrm{~cm}^{-1}$ dan $794,67 \mathrm{~cm}^{-1}$ yang merupakan vibrasi tekuk $\mathrm{C}-\mathrm{H}$ alifatik. Serapan kuat pada daerah bilangan gelombang $1739,79 \mathrm{~cm}^{-1}$ diduga karena adanya gugus fungsi $\mathrm{C}=0$. Keberadaan serapan rentangan $\mathrm{C}-\mathrm{H}$ alifatik ditunjukkan dengan adanya pita serapan yang tajam dengan intensitas kuat pada bilangan gelombang $2920,23 \mathrm{~cm}^{-1}$ dan 2850,79 $\mathrm{cm}-1$, hal ini memberi petunjuk kemungkinan adanya gugus metil $\left(\mathrm{CH}_{3}\right)$ dan metilena $\left(\mathrm{CH}_{2}\right)$. Dugaan ini diperkuat oleh adanya serapan pada daerah bilangan gelombang $1463,97 \mathrm{~cm}^{-1}$ dan 1379,10 $\mathrm{cm}^{-1}$ yang merupakan serapan dari bengkokan $-\mathrm{CH}_{2}$ dan $-\mathrm{CH}_{3}$ yang mengindikasikan adanya gugus gem dimetil sebagai ciri khas senyawa triterpenoid [11]. Adanya serapan kuat pada bilangan gelombang 466,37 $\mathrm{cm}^{-1}$ merupakan serapan dari gugus sikloheksana.

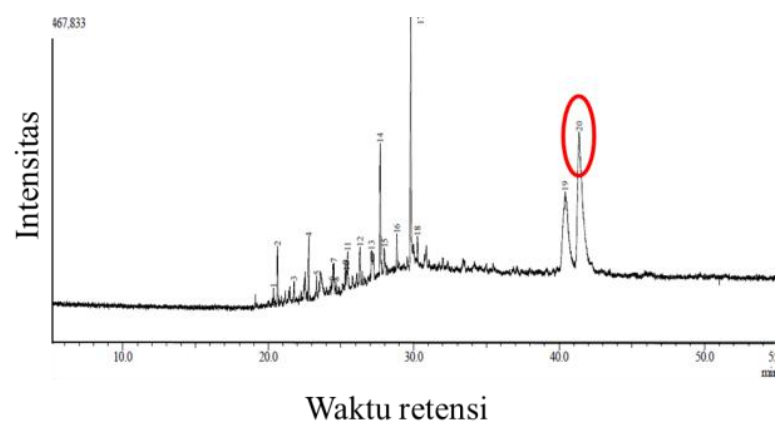

Gambar 5. Kromatogram GC isolat

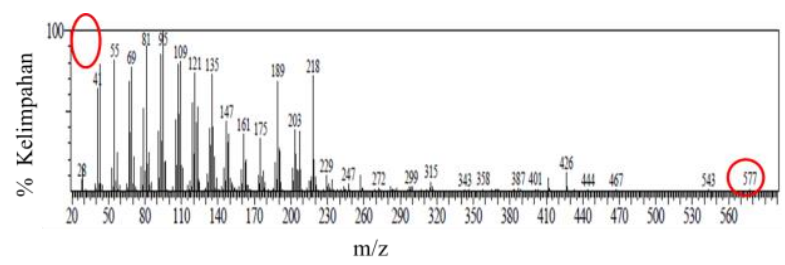

Gambar 6. Spektrogram massa isolat

Hasil analisis dengan GC menunjukkan bahwa isolat belum murni dengan adanya 20 puncak dan waktu retensi yang berbeda. Senyawa pada puncak nomor 20 dengan waktu retensi 41,376 menit merupakan senyawa komponen terbesar pada isolat. Spektrogram massa senyawa puncak nomor 20 dengan waktu retensi 41,376 menit, base peak m/e 95 dan berat molekul sebesar 577 $\mathrm{g} / \mathrm{mol}$ menunjukkan pola fragmentasi sebagai berikut: $\mathrm{m} / \mathrm{e} 577\left[\mathrm{M}^{+}\right] ; 426 ; 218 ; 203 ; 189 ; 175 ; 161 ; 147 ; 135$; 121;109; 95; 81; 69; 55; 41. Pola ini sesuai dengan pola fregmentasi lupeol sebagai berikut: $\mathrm{m} / \mathrm{e} 426\left[\mathrm{M}^{+}\right]$; 218; 
$207 ; 189 ; 175 ; 161 ; 147 ; 135 ; 121 ; 109 ; 95 ; 81 ; 69 ; 55$ [12]. Untuk klarifikasi perkiraan struktur senyawa puncak nomor 20, maka dilakukan analisis mengenasi pola fragmentasi strukturnya, disajikan pada gambar 7 . Berdasarkan analisis tersebut, maka diperkirakan bahwa puncak nomor 20 merupakan puncak dari senyawa triterpenoid yang memiliki kerangka mirip dengan kerangka senyawa lupeol. Namun, perlu dilakukan analisis lebih lanjut menggunakan instrumen NMR untuk mengetahui kepastian kerangkan struktur dari senyawa pada puncak nomor 20 .

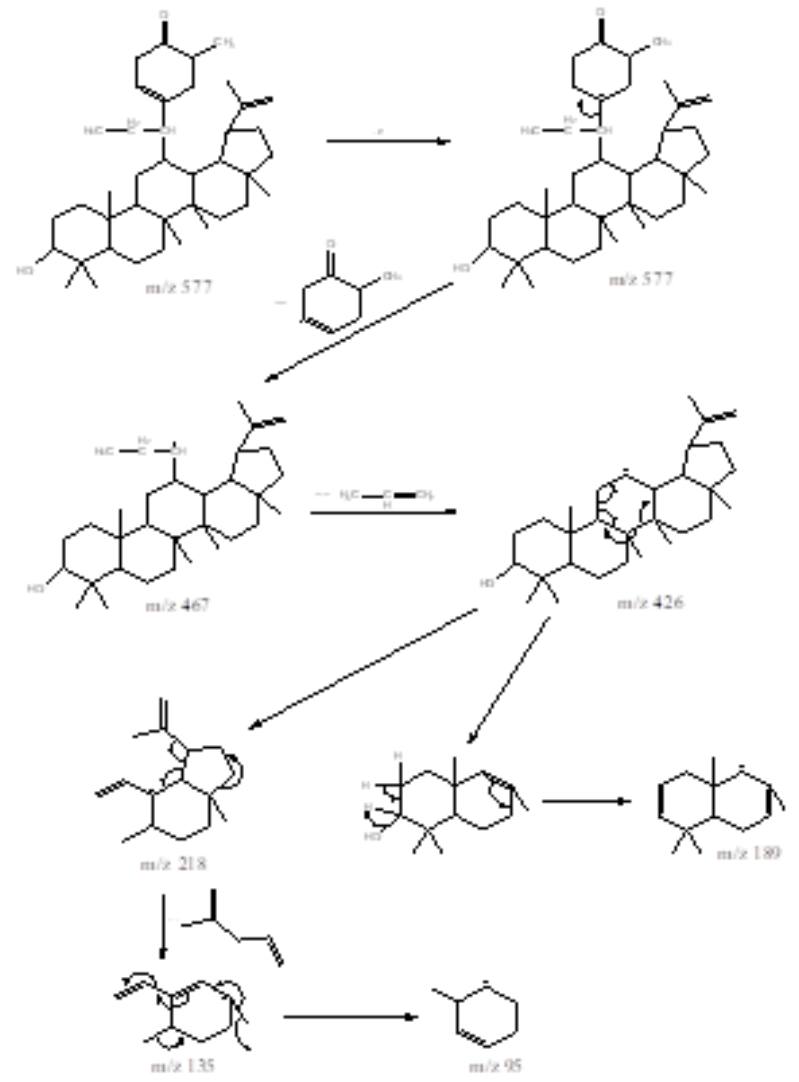

Gambar 7. Perkiraan fragmentasi senyawa puncak nomor 20

Uji sitotoksik dilakukan terhadap ekstrak etanol, fraksi $n$-heksana, fraksi etil asetat, dan fraksi metanol. Penelusuran aktivitas toksik pada isolat tidak dapat dilakukan karena jumlah isolat yang diperoleh sangat sedikit. Pengujian dilakukan dengan metode BSLT menggunakan larva Artemia salina Leach. yang berumur 2 hari. Berdasarkan Moshi dkk. [13] harga $30 \mathrm{ppm}<\mathrm{LC}_{50}$ $\leq 100$ ppm bersifat sedikit toksik, harga $\mathrm{LC}_{50}>100 \mathrm{ppm}$ bersifat tidak toksik. Oleh karena itu, dapat disimpulkan bahwa ekstrak etanol dan fraksi $n$-heksana bersifat tidak toksik sedangkan fraksi etil asetat dan fraksi metanol bersifat sedikit toksik dengan harga $\mathrm{LC}_{50}$ berturut-turut $100 \mathrm{ppm}$ dan 78,735 ppm ditunjukkan pada tabel 1.
Tabel 1: Hasil pengamatan kematian larva Artemia salina Leach. pada ekstrak etanol, fraksi $n$-heksana, fraksi etil asetat, dan fraksi metanol

\begin{tabular}{|c|c|c|c|c|c|c|c|c|}
\hline \multirow{2}{*}{$\begin{array}{c}\text { Sampel } \\
\text { (Ekstrak) }\end{array}$} & \multirow{2}{*}{$\begin{array}{l}\text { Konsentrasi } \\
(\mathrm{ppm})\end{array}$} & \multicolumn{3}{|c|}{$\begin{array}{c}\Sigma \text { larva yang } \\
\text { diujikan }\end{array}$} & \multicolumn{3}{|c|}{$\Sigma$ larva yang mati } & \multirow{2}{*}{$\mathrm{LC}_{50}(\mathrm{ppm})$} \\
\hline & & 1 & 2 & 3 & 1 & 2 & 3 & \\
\hline \multirow{3}{*}{$\begin{array}{l}\text { Ekstrak } \\
\text { etanol }\end{array}$} & 10 & $\begin{array}{l}1 \\
3\end{array}$ & 11 & 13 & 5 & 5 & 4 & \multirow{3}{*}{196,327} \\
\hline & 100 & $\begin{array}{l}1 \\
3\end{array}$ & 12 & 10 & 7 & 3 & 4 & \\
\hline & 1000 & $\begin{array}{l}1 \\
0\end{array}$ & 13 & 13 & 9 & 13 & 12 & \\
\hline \multirow{3}{*}{$\begin{array}{l}\text { Fraksi n- } \\
\text { heksana }\end{array}$} & 10 & $\begin{array}{l}1 \\
2\end{array}$ & 10 & 10 & 5 & 2 & 4 & \multirow{3}{*}{106,556} \\
\hline & 100 & $\begin{array}{l}1 \\
1\end{array}$ & 12 & 10 & 3 & 7 & 5 & \\
\hline & 1000 & $\begin{array}{l}1 \\
3\end{array}$ & 11 & 17 & 13 & 11 & 17 & \\
\hline \multirow{3}{*}{$\begin{array}{c}\text { Fraksi etil } \\
\text { asetat }\end{array}$} & 10 & $\begin{array}{l}1 \\
1\end{array}$ & 13 & 14 & 2 & 2 & 4 & \multirow{3}{*}{100,000} \\
\hline & 100 & $\begin{array}{l}1 \\
1\end{array}$ & 14 & 15 & 11 & 4 & 5 & \\
\hline & 1000 & $\begin{array}{l}1 \\
1\end{array}$ & 10 & 12 & 11 & 10 & 12 & \\
\hline \multirow{3}{*}{$\begin{array}{l}\text { Fraksi } \\
\text { methanol- } \\
\text { air }\end{array}$} & 10 & $\begin{array}{l}1 \\
0\end{array}$ & 11 & 12 & 0 & 3 & 2 & \multirow{3}{*}{78,735} \\
\hline & 100 & $\begin{array}{l}1 \\
2\end{array}$ & 15 & 13 & 4 & 11 & 10 & \\
\hline & 1000 & $\begin{array}{l}1 \\
2\end{array}$ & 19 & 15 & 12 & 19 & 15 & \\
\hline
\end{tabular}

\section{Kesimpulan}

Isolat yang diperoleh berupa padatan berwarna putih dengan rendemen $0,28 \%(b / b)$. Karakterisasi isolat dengan spektrofotometer UV-Vis tidak menunjukkan adanya serapan. Spektrogram FTIR menunjukkan adanya gugus $-\mathrm{OH}, \mathrm{C}=\mathrm{C}, \mathrm{C}=\mathrm{O},-\mathrm{CH} 3$ dan -CH2. Sedangkan spektrogram MS menunjukkan bahwa isolat memiliki bobot molekul $577 \mathrm{~g} / \mathrm{mol}$ dan memiliki pola fragmentasi mirip senyawa lupeol ( $\mathrm{SI}=88 \%$ ). Hasil uji aktivitas sitotoksik menunjukkan ekstrak etanol dan fraksi $\mathrm{n}$-heksana bersifat tidak toksik sedangkan fraksi etil asetat dan fraksi metanol-air memiliki sifat sedikit toksik dengan harga $\mathrm{LC}_{50}$ berturut-turut $100 \mathrm{ppm}$ dan $78,735 \mathrm{ppm}$.

\section{Daftar Pustaka}

[1] RHMJ Lemmens, N Wulijarni-Soetjipto, Prosea: Plant Resources of South-East Asia, Pudoc, Wageningen, The Netherlands, 23, (1992)

[2] P Masoko, J Picard, JN Eloff, Antifungal activities of six south African Terminalia species (Combretaceae), Journal of Ethnopharmacology, 99, 2, (2005) 301-308

[3] K Anam, RM Widharna, D Kusrini, $\alpha$-Glucosidase inhibitor activity of Terminalia species, IJPInternational Journal of Pharmacology, 5, 4, (2009) 277-280

[4] K Anam, AG Suganda, EY Sukandar, L Broto S Kardono, Antibacterial effect of component of Terminalia muelleri Benth. Against Staphylococcus aureus, International Journal of Pharmacology, 6, 4, (2010) 407-412

[5] Andrea K Bigham, Thomas A Munro, Mark A Rizzacasa, Roy M Robins-Browne, Divinatorins AC, New Neoclerodane Diterpenoids from the Controlled Sage Salvia d ivinorum, Journal of natural products, 66, 9, (2003) 1242-1244

[6] ASR Anjaneyulu, AV Raghava Reddy, Gopal R Mallavarapu, RS Chandrasekhara, 3-acetylmaslinic 
acid from the root bark of Terminalia alata, Phytochemistry, 25, 11, (1986) 2670-2671

[7] B. N. Meyer, N. R. Ferrigni, J. E. Putnam, L. B. Jacobsen, D. E. Nichols, J. L. McLaughlin, Brine Shrimp: A Convenient General Bioassay for Active Plant Constituents, Planta Med, 45, 05, (1982) 31-34 http://dx.doi.org/10.1055/s-2007-971236

[8] Norman R. Farnsworth, Biological and phytochemical screening of plants, Journal of Pharmaceutical Sciences, 55, 3, (1966) 225-276 http://dx.doi.org/10.1002/jps.2600550302

[9] Hildebert Wagner, Sabine Bladt, Plant drug analysis: a thin layer chromatography atlas, $2^{\text {th }}$ Edition ed., Springer Science \& Business Media, Germany, 1996.

[10] Robert M Silverstein, Francis X Webster, David J Kiemle, David L Bryce, Spectrometric Identification of Organic Compounds, John wiley \& sons, 1981.

[11] Leda Mathias, Ivo JC Vieira, Raimundo Braz-Filho, Edson Rodrigues Filho, A new pentacyclic triterpene isolated from Myroxylon balsamum (syn. Myroxylon peruiferum), Journal of the Brazilian Chemical Society, 11, 2, (2000) 195-198 http://dx.doi.org/10.1590/S010350532000000200017

[12] Tatiane $C$ de Carvalho, Aline M Polizeli, Izabel CC Turatti, Marcela E Severiano, Carlos E de Carvalho, Sérgio R Ambrósio, Antônio EM Crotti, Uir S de Figueiredo, Paulo C Vieira, Niege AJC Furtado, Screening of filamentous fungi to identify biocatalysts for lupeol biotransformation, Molecules, 15, 9, (2010) 6140-6151 http://dx.doi.org/10.3390/molecules15096140

[13] MJ Moshi, E Innocent, JJ Magadula, DF Otieno, A Weisheit, PK Mbabazi, RSO Nondo, Brine shrimp toxicity of some plants used as traditional medicines in Kagera region, north western Tanzania, Tanzania journal of health research, 12, 1, (2010) 63-67 http://dx.doi.org/10.4314/thrb.v12i1.56287 